\title{
Main streams in the Construction of Biosensors and Their Applications
}

\author{
Pavla Martinkova ${ }^{1}$, Adam Kostelnik ${ }^{1,2}$, Tomas Valek ${ }^{1}$, Miroslav Pohanka ${ }^{1,3}$ \\ ${ }^{1}$ Faculty of Military Health Sciences, University of Defence, Trebesska 1575, 50001 Hradec Kralove, \\ Czech Republic \\ ${ }^{2}$ Faculty of Chemical Technology, University of Pardubice, Studentska 95, 53210 Pardubice, Czech \\ Republic \\ ${ }^{3}$ Department of Geology and Pedology, Mendel University in Brno, Czech Republic \\ *E-mail: miroslav.pohanka@gmail.com
}

doi: $10.20964 / 2017.08 .02$

Received: 29 March 2017 / Accepted: 22 May 2017 / Published: 12 July 2017

\begin{abstract}
Biosensors are quite simple but accurate analytical devices which have been practically used since the half of $20^{\text {th }}$ century and their popularity is still growing. This review is focused on description and summarization of general biosensors construction with introducing of practical examples including graphical explanations. The most applied biorecognition elements like enzymes, genetic information, antibodies, viable cells and, types of standard immobilization techniques and usually used transducers like the optical and electrochemical are given here. Current top topics in biosensing, modern approaches, novel materials and principals and unique combination of transducers and biorecogniction elements are also explained. Survey of actual literature is also provided.
\end{abstract}

Keywords: Biosensor; biorecognition element; transducer; immobilization method; nanotechnologies

\section{$\underline{\text { FULL TEXT }}$}

(C) 2017 The Authors. Published by ESG (www.electrochemsci.org). This article is an open access article distributed under the terms and conditions of the Creative Commons Attribution license (http://creativecommons.org/licenses/by/4.0/). 